\title{
Ultrastructure of Spontaneous and Transplanted Pituitary Tumors in Laboratory Animals
}

\author{
RICARDO V. LLOYD \\ Department of Pathology, University of Michigan Medical Center, Ann Arbor, Michigan 48109
}

\author{
KEY WORDS Immunocytochemistry, Electron microscopy, In situ hybridization
}

\begin{abstract}
The present review examines ultrastructural studies of pituitary tumors in laboratory animals. Such studies have been facilitated by the development of newer techniques such as immunocytochemistry and in situ hybridization. Using these methods it has been possible to correlate morphological features with function by characterizing specific pituitary hormones in secretory granules and analyzing the messenger ribonucleic acids produced by specific cell types. Analyses of spontaneous and experimentally induced tumors have provided a great deal of insight into the function and ultrastructure of these neoplasms. The description of tumor cells producing more than one hormone has been facilitated by immunocytochemical analyses. Studies of transgenic models of pituitary hyperplasia and tumor development are expanding our knowledge about the ultrastructure and about other aspects of pituitary tumors in a more controlled experimental setting. The production of various hormones by the same pituitary tumors and even the same tumor cells indicates that complex regulatory mechanisms must be analyzed by a combination of ultrastructural and other techniques to learn more about growth and hormone secretion in pituitary neoplasms.
\end{abstract}

\section{INTRODUCTION}

There has been a striking increase in studies of normal and neoplastic pituitary tissues in laboratory animals during the past two decades. This has been stimulated in part by the development of various techniques used to learn more about the cell biology, secretion, and molecular biology of pituitary cells. These include: immunocytochemical techniques at the light and electron microscopic level (Bendayan et al., 1986; Furth et al., 1976; Horvath and Kovacs, 1988; Kovacs and Horvath, 1986; McComb et al., 1984); the reverse hemolytic plaque assay to analyze hormone secretion by individual cells (Frawley et al., 1985a,b; Lloyd et al., 1987a,b); Northern and in situ hybridization techniques to study gene expression by tissues and by individual cells (Pasteels et al. 1972; Gee and Roberts, 1983; Khachaturian et al., 1986; Lloyd, 1987; Lloyd and Landefeld, 1986; Lloyd et al., 1986b, 1988, 1989; Song et al., 1989). These techniques in combination with ultrastructural studies have contributed a great deal to our understanding of the ultrastructure of pituitary tumors. Ultrastructural immunocytochemistry has allowed for a more exact classification of anterior pituitary cells (Fig. 1) and neoplasms. In this review of the ultrastructure of pituitary tumors the rat model will be emphasized, since most studies have been done with this species. Studies of spontaneous tumors, experimentally induced tumors, and cultured tumor cells will be discussed. The morphological alterations induced by specific hormonal treatment will also be examined.

\section{SPONTANEOUS TUMORS}

The development of spontaneous pituitary tumors has been described in many species of animals, al- though these tumors have been studied most extensively in the rat and mouse. Spontaneous anterior pituitary tumors have been described in fish, parakeets, buffalo, cows, dogs, horses, humans as well as rats and mice (Beech, 1981; Costoff, 1973; El Eltreby et al., 1977; Gardner et al., 1953; Kovacs and Horvath, 1986; Liebelt, 1979; Olivier et al., 1975). Schlumberger (1956) described three spontaneous pituitary tumors in parakeets which were used to establish transplantable strains. These transplantable tumors produced accelerated body growth in young birds and hyperglycemic obesity in older birds (Schlumberger and Rudolph, 1959). Cushing's syndrome secondary to pituitary basophilic adenomas associated with bilateral hyperplasia of the adrenal cortex and diabetes insipidus have been described in dogs (Coffin and Munson, 1953). The enlarging tumor mass probably produced pressure atrophy of the posterior pituitary.

The incidence of spontaneous tumors in rats and mice varies with the sex, age, and strain of animals. In general, the frequency of tumors increases with age in all strains examined. Female rats and mice usually have a higher incidence of pituitary gland tumors than their male counterparts. The number of spontaneous tumors of the anterior pituitary gland of mice has been relatively small and most of these have been in very old animals (Liebelt, 1979). A recent study of mammotroph adenomas in pituitaries of aging female C57BL/6J

\footnotetext{
Received March 24, 1990; accepted in revised form May 30, 1990.

Address reprint requests to R.V. Lloyd, M.D., Ph.D., Department of Pathology, University of Michigan Hospitals, 2G332/Box 0054, Ann Arbor, Michigan 481090054 .
} 


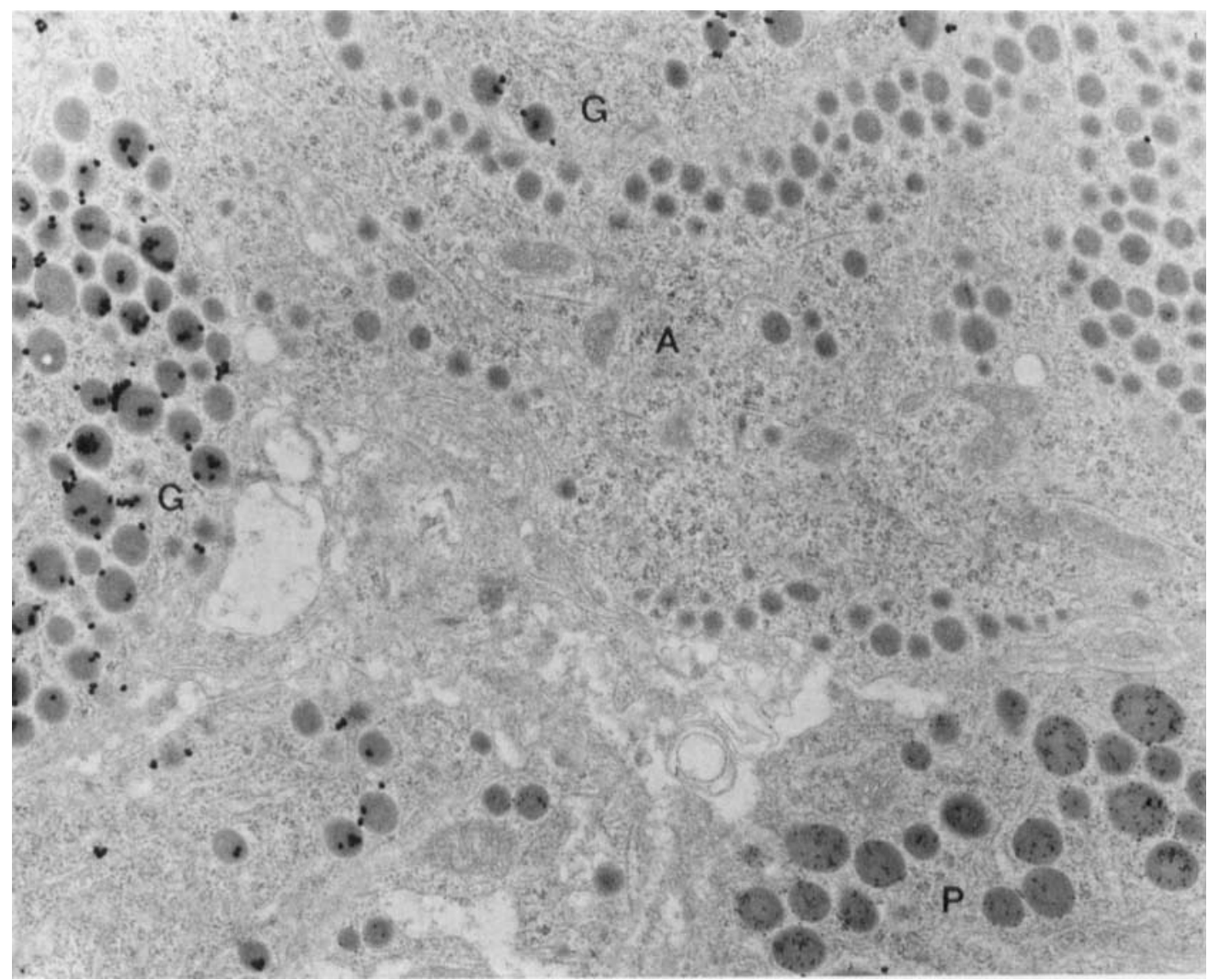

Fig. 1. Normal rat anterior pituitary cells. Double immunocytochemical labeling with antibodies against GH and PRL reveals GH cells with $40 \mathrm{~nm}$ colloidal gold particles $(\mathrm{G})$ and a PRL cell with $15 \mathrm{~nm}$ gold particles (P). A putative ACTH cell (A) is unlabeled. $\times 17,700$.

mice found a high incident of prolactin (PRL) cell hyperplasia. By 28-30 months of age, many mice had developed mammotroph adenomas (Clayton et al., 1984). The localization of these tumors in the pituitary appears to be quite specific. Gorden et al. (1987) reported that in aging female $\mathrm{C} 57 \mathrm{BL} / 6 \mathrm{~J}$ mice more than $90 \%$ of the observed tumors (26/30) involved the lateral and adjacent zones of the pars distalis.

Many studies of spontaneous pituitary tumors in rats have been reported. These data have been summarized recently by Carlton and Gries (1983) and by McComb et al. (1984). Some of the reported studies ranged from examination of a small number of animals to studies of large colonies of rats which were used to examine aging changes and to study degenerative and neoplastic diseases. The techniques used to identify adenomas have been quite variable including the numbers of sections of pituitaries examined and the size of tumors described. For example, Boorman and Hollander (1973) found $199 / 290$ or $69 \%$ adenomas in female Wistar rats 12-43 months of age while Ueberberg and Lutzen (1979) found $55 / 300(18.3 \%)$ adenomas in female Wistar rats 24-30 months of age.

Various proliferative lesions are seen in abnormal pituitaries of aging rodents. These include diffuse hyperplasias, hyperplastic nodules, and true adenomas (McComb et al., 1980, 1984). It may be difficult to separate diffuse hyperplasia from enlargement of the pituitary secondary to physiological changes such as pregnancy unless the percentages of various cell types in the pituitaries are known. Treatment with various drugs and/or end organ ablation can lead to pituitary cell hyperplasia (Figs. 2-4). Diffuse hyperplasia may be seen in the pituitary of older rodents, but the relationship between hyperplasia and spontaneous pituitary neoplasms has not been clearly elucidated.

Hyperplastic nodules usually consist of groups of enlarged anterior pituitary cells. These nodules were defined by McComb et al. (1984) as proliferative lesions that did not possess a demonstrable pseudocapsule at the light microscopic level. However, the distinction between a hyperplastic nodule and an adenoma can be very difficult. Adenomas are usually solitary lesions associated with compression of the adjacent nontumorous pituitary and with formation of a pseudocapsule. Pleomorphism and mitoses may be seen in hyperplastic nodules and adenomas. Local invasion may be present in adenomas. Pituitary carcinomas are characterized 

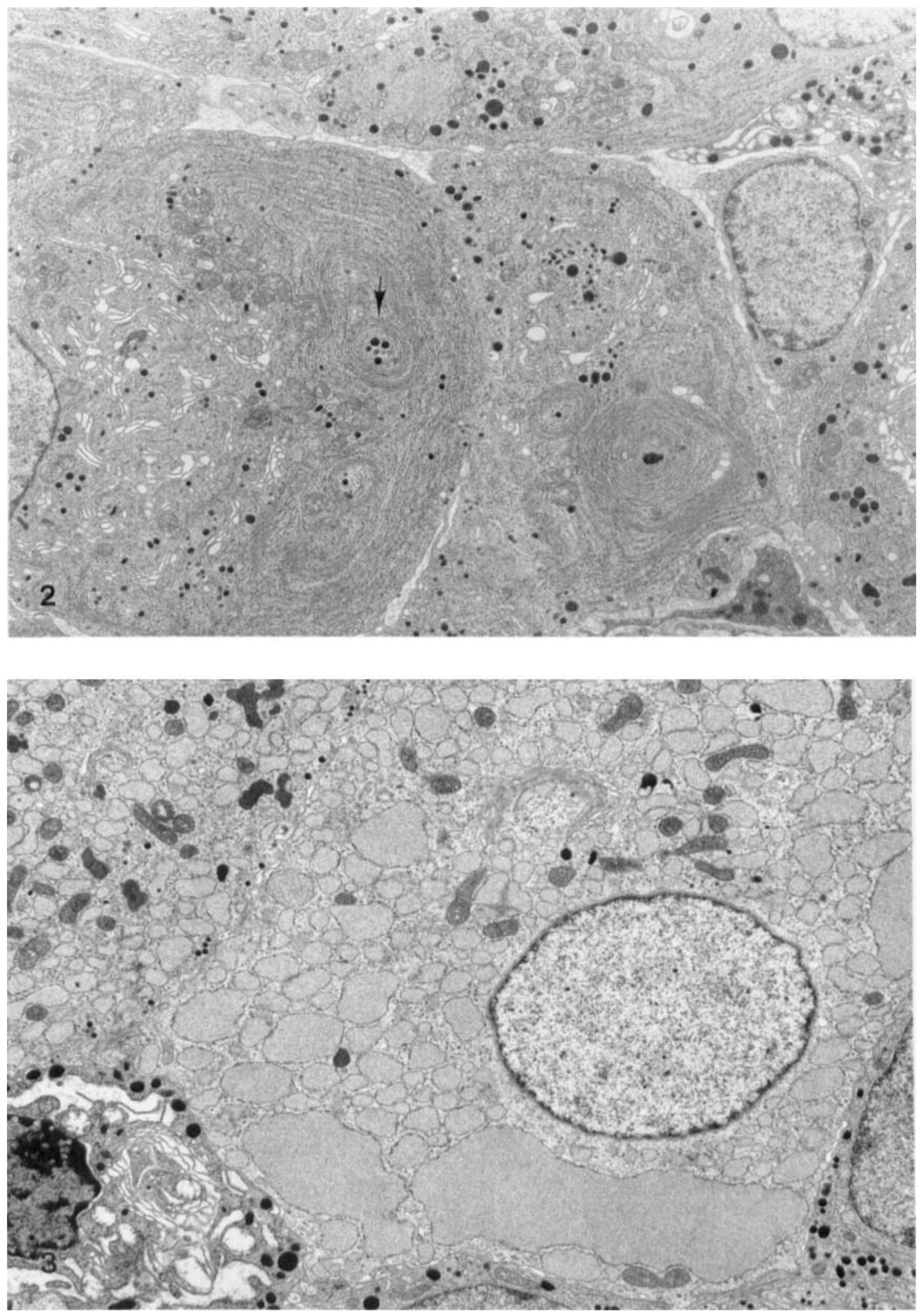

Fig. 2. PRL cell hyperplasia in an estrogen treated female rat. The RER is markedly increased with nebenkern formation (arrow) and the Golgi region is prominent. $\times 5,800$.
Fig. 3. TSH cell hyperplasia in a female rat treated with propylthiouracil for 60 days. There is markedly dilated RER and few secretory granules in the cytoplasm of the thyroidectomy cell. $\times 8,300$. 


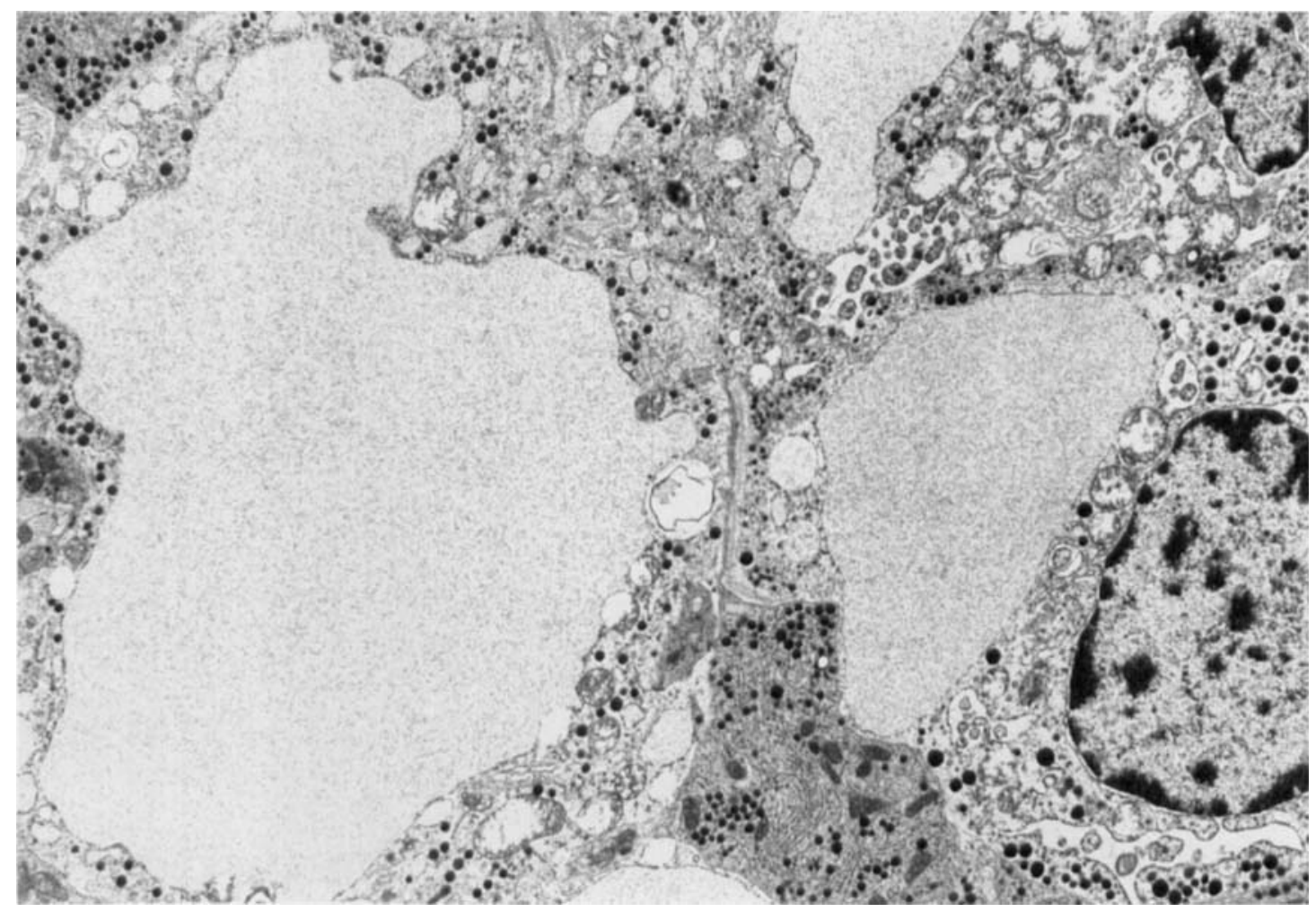

Fig. 4. Gonadotroph cell hyperplasia in a female rat ovariectomized for 30 days. The gonadectomy cells have cystically dilated RER and moderate numbers of secretory granules. $\times 8,500$.

by the presence of metastatic neoplasms. They often show pleomorphism and mitoses and may have atypical mitoses.

Spontaneous pituitary tumors have been classified by immunohistochemistry, in situ hybridization, and ultrastructural features. These include tumors producing PRL, growth hormone (GH), mixed PRL-GH, follicle-stimulating hormone (FSH), luteinizing hormone (LH), thyroid-stimulating hormone (TSH), adrenocorticotropin (ACTH), and undifferentiated adenomas (Barsoum et al., 1985; Lloyd et al., 1989; Majeed et al., 1980; McComb et al., 1984; Sandusky et al., 1988; Trouillas and Girod, 1988). PRL adenomas are the most common tumors (Figs. 5, 6). In a recent study by Sandusky et al., (1988) of 100 Sprague-Dawley and 100 Fisher 344 (F344) rats, 64\% and 56.6\%, respectively, of tumors were immunoreactive for PRL only, while $21 \%$ of tumors in F344 rats were mixed PRL-GH adenomas. In situ hybridization studies of spontaneous tumors have reported similar findings as immunochemical studies (Lloyd et al., 1989). However, in some cases the mRNA was detected in cells that did not have immunoreactive hormones.

Ultrastructural studies of spontaneous rat pituitary tumors (Table 1) show features that are similar to pituitary adenomas in humans. For example, misplaced exocytosis (Fig. 5) is commonly seen in PRL adenomas (McComb et al., 1984). PRL adenomas may be sparsely or densely granulated. The Golgi region is often prom- inent and perinuclear. Abundant rough endoplasmic reticulum (RER) with nebenkern formation is ofter present. Sparsely granulated adenomas have secretory granules measuring 150-200 nm while densely granulated adenomas have granules measuring up to 600 $\mathrm{nm}$ in maximum diameter. $\mathrm{GH}$ adenomas are often pleomorphic with a well developed Golgi region, single profiles, or stacks of RER and granules measuring $300-400 \mathrm{~nm}$ in diameter. Mixed PRL-GH adenomas can be bimorphous or monomorphous. The Golgi region is often vesicular and RER may show nebenkern formation or be in short single stacks. Secretory granules vary from $100-200 \mathrm{~nm}$ in diameter, although occasional larger granules of 300-600 nm may be seen. LH producing adenomas often express FSH also. These tumors may be sparsely granulated, papillary, or solid. There is a prominent Golgi region and prominent dilated profiles of RER. Secretory granules range from $100-150 \mathrm{~nm}$ in diameter. TSH producing adenomas are uncommon. They are often densely granulated with thyroidectomy cells and mitotic figures. The Golgi region is often prominent and the RER is in single dilated profiles. Secretory granules range from $100-300 \mathrm{~nm}$ in diameter. Plurihormonal adenomas may produce various hormones including PRL-ACTH or PRL-LH and TSH. The Golgi regions of these adenomas are prominent and the RER ranges from single dilated stacks to long or short multiple profiles. Secretory granules are variable with densely granulated clusters ranging 

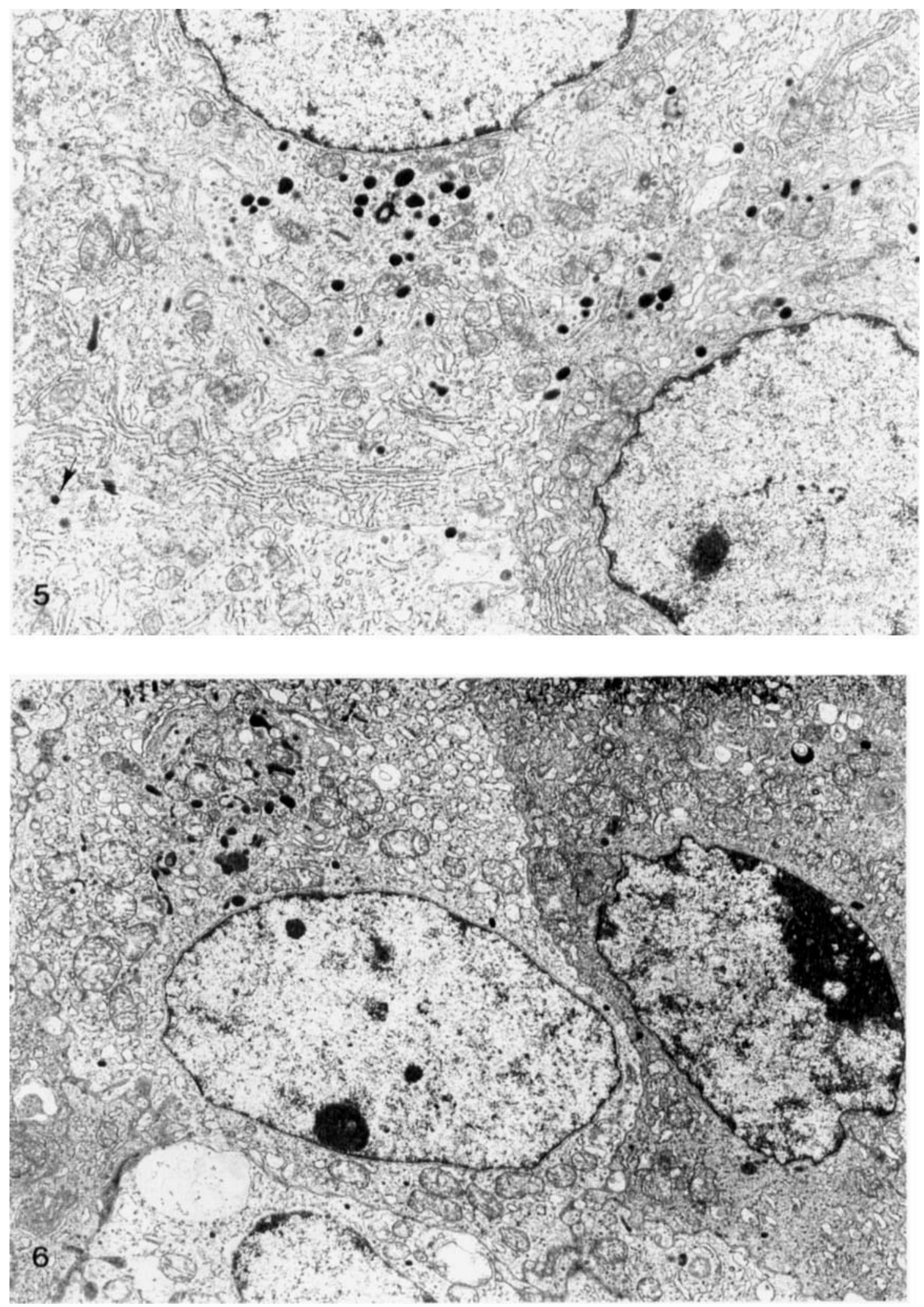

Fig. 5. Spontaneous pituitary adenoma from a 2 year old female rat. The tumor stained positively with a PRL antibody. There is prominent RER. The pleomorphic secretory granules range in size from $100-600 \mathrm{~nm}$. Reverse exocytosis (arrow) is present. $\times 12,300$.
Fig. 6. Spontaneous PRL producing pituitary adenoma from a 2 year old female rat. One cell has a prominent Golgi region and secretory granules while the two other cells have few secretory granules. $\times 8,500$. 
TABLE 1. Ultrastructural features of spontaneous rat pituitary tumors ${ }^{1}$

\begin{tabular}{|c|c|c|c|c|}
\hline $\begin{array}{l}\text { Tumor type } \\
\text { region }\end{array}$ & $\begin{array}{l}\text { Ultrastructural } \\
\text { classification }\end{array}$ & $\begin{array}{l}\text { Storage } \\
\text { granules }\end{array}$ & RER & Golgi \\
\hline PRL producing & $\begin{array}{l}\text { Sparsely granulated } \\
\text { Densely granulated }\end{array}$ & $\begin{array}{l}\text { Few, small } \\
150-200 \mathrm{~nm} \\
\text { Many, large } \\
250-600 \mathrm{~nm}\end{array}$ & $\begin{array}{l}\text { Prominent } \\
\text { nebenkern } \\
\text { Short single } \\
\text { profiles }\end{array}$ & $\begin{array}{l}\text { Perinuclear } \\
\text { Prominent }\end{array}$ \\
\hline $\begin{array}{l}\text { GH producing } \\
\& \mathrm{r} 300-\end{array}$ & $\begin{array}{l}\text { Pleomorphic } \\
\text { profiles }\end{array}$ & $\begin{array}{r}\text { Moderate } \\
400 \mathrm{~nm}\end{array}$ & Single & Prominent \\
\hline $\begin{array}{l}\text { Mixed PRL/GH } \\
\text { producing }\end{array}$ & $\begin{array}{l}\text { Sparsely and } \\
\text { densely granulated }\end{array}$ & $\begin{array}{l}150-200 \mathrm{~nm} \\
\quad \text { or } 300-600 \mathrm{~nm}\end{array}$ & $\begin{array}{l}\text { Nebenkern } \\
\text { formation }\end{array}$ & Prominent \\
\hline LH producing & $\begin{array}{l}\text { Sparsely and } \\
\text { densely granulated }\end{array}$ & $100-150 \mathrm{~nm}$ & $\begin{array}{l}\text { Prominent } \\
\text { dilated } \\
\text { profiles }\end{array}$ & Prominent \\
\hline TSH producing & $\begin{array}{l}\text { Densely } \\
\text { granulated }\end{array}$ & $\begin{array}{l}150-150 \mathrm{~nm} \\
\text { and } 300 \mathrm{~nm}\end{array}$ & $\begin{array}{l}\text { Single } \\
\text { dilated } \\
\text { profiles }\end{array}$ & Prominent \\
\hline Plurihormonal & Pleomorphic cells & $\begin{array}{c}100-200 \mathrm{~nm}, \\
300-350 \mathrm{~nm}, \\
600-700 \mathrm{~nm}\end{array}$ & Variable & Prominent \\
\hline
\end{tabular}

${ }^{1}$ Data from McComb et al., 1984.

from $100-200 \mathrm{~nm}$ up to $600-700 \mathrm{~nm}$ in diameter (McComb et al., 1984).

Pituitary gonadotroph adenomas in old SpragueDawley rats often express both FSH $\beta$ and LH $\beta$ subunits and often coexist with PRL containing tumors in the same pituitary gland (McComb et al., 1985). The cells are often arranged in a trabecular pattern. The sparsely granulated gonadotroph adenomas have large nuclei, a diffuse chromatin pattern, and prominent nucleoli. Secretory granules are quite variable from cell to cell. The Golgi regions are often extensive, but the honeycomb pattern observed in the gonadotroph of human females (Kovacs and Horvath, 1986) has not been observed in rats (McComb et al., 1985). Accumulation of large electron dense bodies, probably lysosomes, is often seen in the golgi area. Sano et al. (1989) recently described spontaneous pituitary gonadotroph nodules in aging male Lobund-Wistar rats 26 months or older. The development of these nodules was delayed by food restriction and germ-free states. Interestingly, the remainder of the pituitary also contained hyperactive gonadotrophs similar to those in the gonadotroph nodules. By electron microscopy the gonadotrophs in the extranodular tissue had enlarged cytoplasm, prominent Golgi regions, and markedly dilated RER and secretory granules measuring $200-300 \mathrm{~nm}$ in diameter. Ultrastructural studies of the gonadotrophs in the nodules were not reported (Sano et al., 1989).

Although the etiology of spontaneous pituitary tumors in rats and mice is unknown, various theories have been proposed to explain the pathogenesis of these neoplasms. These include: 1) target organ failure with prolonged hyperplasia of pituitary cells leading to loss of negative feedback regulation (Furth, 1955, 1969; Furth et al., 1973, 1976) 2) loss of hypothalamic regulation of pituitary secretion such as dopaminergic control of PRL secretion (Sarkar et al., 1982); and 3) changes in the vacular supply in the pituitary gland possibly leading to decreased delivery of dopamine and other regulatory factors to the pituitary gland (Elias and Weiner, 1984; Lloyd et al., 1986a). The nutritional state of the animal is also important in tumor development, since in some experiments rats with the highest food intake had an increased frequency of pituitary tumors and pituitary tumor incidence usually correlated directly with body weight (Ross et al., 1970).

\section{TRANSPLANTABLE TUMORS}

Transplantable pituitary tumors have been the most commonly studied pituitary neoplasms in rodents (Furth et al., 1976; Gorbman, 1956; Kwa, 1961; Russfield, 1966). There are species differences in hormone sensitivity of tumors. For example estrogen-induced transplantable mammotropic tumors are more hormone dependent in rats than in mice (Liebelt, 1979). In other rodents in which spontaneous pituitary tumors are uncommon, such as the Syrian hamster, experimentally-induced tumors have also been reported (Russfield, 1963).

Pituitary tumors can be induced by physical and chemical agents or by end organ ablation. The earlier work on pituitary tumor induction has been reviewed extensively by Furth and Clifton (1966) and by Russfield $(1966,1975)$. The induction period usually requires several months or up to one-quarter to one-half of the animal's life span. The functional type of tumor often depends on the induction method. The mechanisms involved in initiation and promotion are not well understood. Drugs such as dimethylbenz(a)anthracene probably act as initiators of pituitary neoplasms (Kao and Ramirez, 1979) while estrogens may induce binding of specific compounds to DNA in the pituitary and other target tissues (Liehr et al., 1986). 


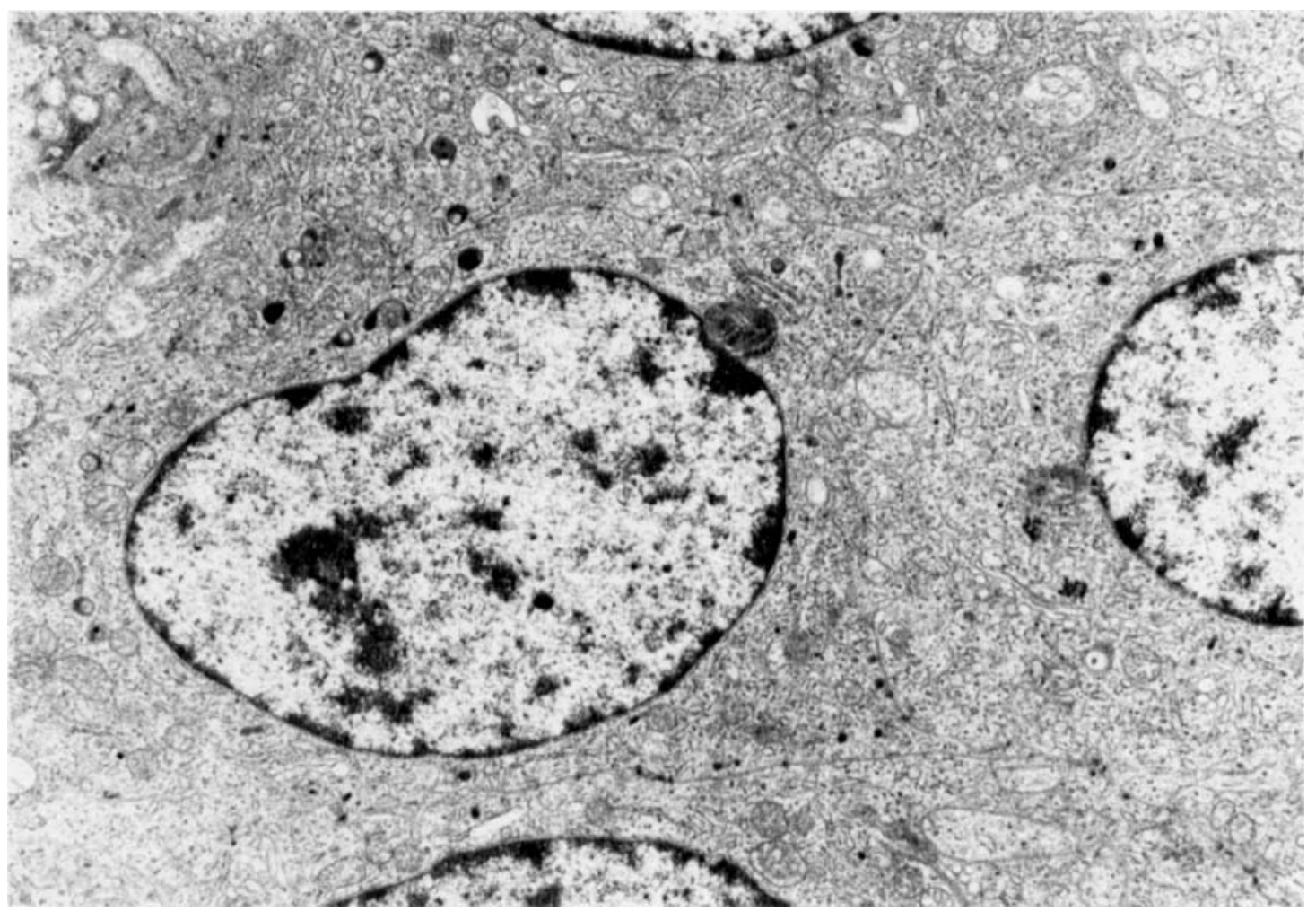

Fig. 7. Transplantable pituitary MtT/W15 tumor. The tumor cells have a few secretory granules $100-250 \mathrm{~nm}$ in diameter. A few cells have prominent Golgi region and RER. Most of the tumor cells have prominent lysosomes. $\times 8,700$.

\section{Chemical Induction}

Estrogen administration has been one of the most common methods of inducing pituitary tumors that secrete PRL (Clifton and Meyer, 1956; Lloyd, 1983; Lloyd et al., 1973; McEuen et al., 1936). The pituitary gland undergoes PRL cell hyperplasia initially. Several transplantations with estrogen support can lead to the development of hormone dependent neoplasms that often produce PRL and GH. In addition to estrogens, other chemicals including N-ethyl-N-nitrosourea, 3.4-dimethylaniline, 0-hydroxyacetamide, 2fluoroacetanilide, and dimethylbenz (a)- anthracene have been reported to induce pituitary hyperplasias and tumors in some strains of rats and mice (Furth and Clifton, 1966; Furth et al., 1973; Kao and Ramirez, 1979; Liebelt, 1979; Stoica and Koestner, 1984).

\section{Ionizing Radiation}

Local or whole body irradiation has been used to induce pituitary tumors in various species. It is most effective when combined with hormonal stimulation since the hormones can induce cell proliferation when the radiation is most effective. Ionizing radiation has produced PRL, ACTH, and TSH secreting adenomas (Furth and Clifton, 1966; Furth et al., 1976).

\section{End Organ Ablation}

Removal of the gonads and thyroid gland can lead to the development of hyperplasia (Fig. 4) and subsequent pituitary tumors after many months in various strains of rats.

\section{Transgenic Models}

The development of transgenic technology has lead to the production of pituitary related abnormalities in several species. Animals with the transgenic $\mathrm{GH}$ or the $\mathrm{GH}$ releasing hormone (GHRH) gene have accelerated body growth (Hammer et al., 1985; Palmiter et al., 1982). Recent studies with a transgene for GHRH have reported marked pituitary enlargement in mice with this transgene (Mayo et al., 1988). Ultrastructural studies have revealed marked GH cell hyperplasia. Many of the hyperplastic cells were mammosomatotrophs which expressed both PRL and GH (Stefaneaunu et al., 1989).

\section{Miscellaneous Methods}

Other techniques that have been used to induce pituitary tumors include blocking hormone synthesis with drugs such as propylthiouracil which affects thyroid hormone synthesis and use of pituitary isografts in various sites such as the anterior chamber of the eye and kidney capsule which can lead to PRL cell hyperplasia and tumor development. 

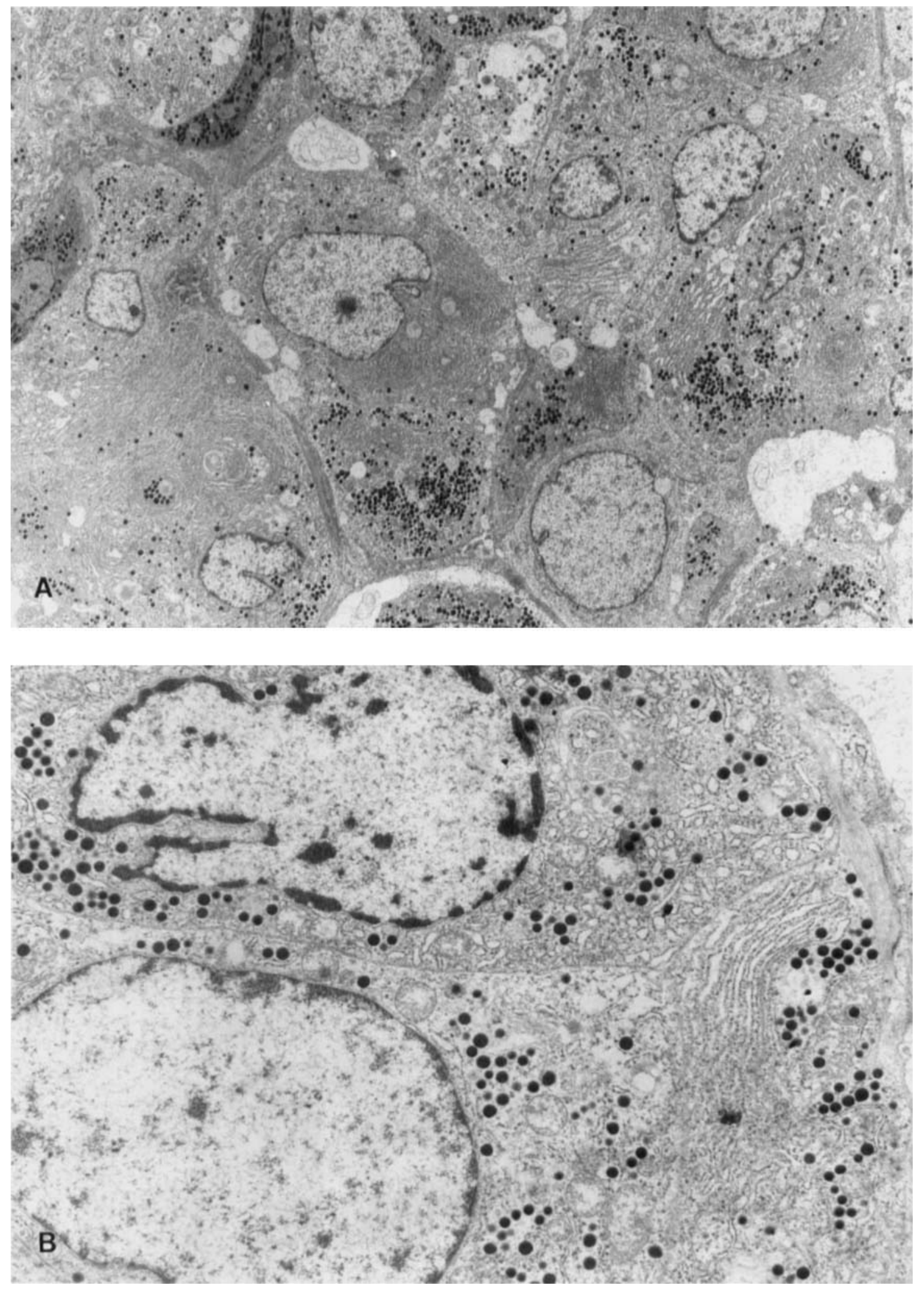

Fig. 8. A: Transplantable pituitary MtT/W15 tumor from a female rat treated with estrogens for 3 weeks. The cells have enlarged nuclei, prominent RER including nebenkern formation and increased numbers of secretory granules $100-380 \mathrm{~nm}$ in diameter. $\times 2,700$. B: Higher magnification of MtT/W15 tumor after estrogen treatment for 3 weeks. The Golgi region and RER are prominent in the tumor cells. $\times 8,700$. 
TABLE 2. Ultrastructural features of transplantable rat pituitary tumors ${ }^{1}$

\begin{tabular}{|c|c|c|c|c|c|}
\hline $\begin{array}{l}\text { Tumor } \\
\text { type }\end{array}$ & Treatment & $\begin{array}{l}\text { Hormone } \\
\text { by ICC }\end{array}$ & $\begin{array}{l}\text { Storage } \\
\text { granules }\end{array}$ & RER & $\begin{array}{l}\text { Golgi } \\
\text { region }\end{array}$ \\
\hline$\overline{\mathrm{MtT} / \mathrm{W} 15}$ & None & PRL/GH & $\begin{array}{l}\text { Few } \\
150 \mathrm{~nm}-\mathrm{PRL} \\
250 \mathrm{~nm}-\mathrm{GH}\end{array}$ & $\begin{array}{l}\text { Short } \\
\text { single } \\
\text { profiles }\end{array}$ & Variable \\
\hline $\mathrm{MtT} / \mathrm{W} 15$ & Estrogen & PRL/GH & $\begin{array}{l}\text { Numerous } \\
100-380 \mathrm{~nm} \\
\text { mosty GH }\end{array}$ & $\begin{array}{l}\text { Nebenkern } \\
\text { formation }\end{array}$ & Prominent \\
\hline $\mathrm{MtT} / \mathrm{F} 4$ & None & $\begin{array}{c}\text { PRL/GH/ } \\
\text { ACTH }\end{array}$ & $\begin{array}{l}\text { Few } \\
\quad 350 \mathrm{~nm} \text { and } \\
100-190 \mathrm{~nm}\end{array}$ & Variable & Variable \\
\hline $\mathrm{MtT} / \mathrm{F} 4$ & Estrogen & $\begin{array}{c}\mathrm{PRL} / \mathrm{GH} / \\
\text { ACTH }\end{array}$ & $\begin{array}{l}\text { Few } \\
\quad 100-150 \mathrm{~nm}\end{array}$ & Prominent & Prominent \\
\hline $\mathrm{MtT} / \mathrm{W} 10$ & None & PRL/GH & $\begin{array}{l}60-115 \mathrm{~nm} \text { PRL } \\
200-480 \mathrm{~nm} \text { GH }\end{array}$ & Variable & Variable \\
\hline $\mathrm{MtT} / \mathrm{W} 5$ & None & $\mathrm{PRL} / \mathrm{GH}$ & $75-190 \mathrm{~nm}$ & Variable & Variable \\
\hline MtT/SA5 & None & PRL/GH & $\begin{array}{l}150-250 \mathrm{~nm} \\
300-600 \mathrm{~nm} \\
100-150 \mathrm{~nm}\end{array}$ & Prominent & $\begin{array}{l}\text { Well devel- } \\
\text { oped }\end{array}$ \\
\hline
\end{tabular}

Abbreviation: ICC, immunocytochemistry.

${ }^{1}$ Data from Baskin et al., 1980; Lloyd et al., 1985a; Makino et al., 1984; McComb et al., 1984; Parsons et al., 1980; Schelin et al., 1964; Trouillas et al., 1984.

\section{Classification of Transplantable Pituitary Tumors}

Many transplantable pituitary tumors have been established and successfully maintained by serial transplantation. The tumors that have been studied most extensively include the MtT/W5, MtT/W10, MtT/W15, $\mathrm{MtT} / \mathrm{F} 4$, and 7315a. These tumors all produce PRL and many also produce GH while a few such as the MtT/F4 and 7315a produce ACTH as well (Furth, 1955, 1969; Furth et al., 1976; McComb et al., 1980, 1981, 1984; Ueda et al., 1968b) (Figs. 7-11). Most tumors remain hormone responsive to estrogens. Recent studies have shown that the growth of MtT/W15 and MtT/F4 tumors can be inhibited by estrogen treatment (Lloyd et al., 1985a; Morel et al., 1982; Pharaboz et al., 1984) (Figs. 8-10) (Table 2). Some transplantable tumors behave like pituitary carcinomas with distant metastases, but most do not metastasize frequently. The GH variant of MStT is a highly malignant variant and the MtT/W15 has been reported to have frequent ovarian and bone metastases (Hollander and Hollander, 1971).

\section{Mammosomatotropic Tumors}

Most of these tumors have been induced by estrogens by Furth and his colleagues (Furth, 1955; Furth et al., 1973, 1976; Ueda et al., 1968a,b, 1970). During the early period of development the tumors produce PRL, but the production of GH usually appears during subsequent transplantation. Some tumors may also produce ACTH. The earliest models of PRL cell hyperplasia and tumor development were reported by McEuen et al. (1936) and Zondek (1936) after chronic estrogen treatment. The hyperplastic pituitaries usually show evidence of excessive PRL production and ultrastructural studies have revealed secretory cytoplasmic granules of $300-900 \mathrm{~nm}$ and abundant RER. With multiple transplantations and an increase in autonomy, the ultrastructural features have included a greater varia- tion in the size of the cells and of cytoplasmic organelles included in secretory granules. Watari and Tsukagoshi (1968) reported on some of the early ultrastructural observations of transplantable PRL secretory pituitary tumors. Early changes included hypertrophied PRL cells with prominent RER. After 6 months the tumors showed decreased numbers of secretory granules and well developed organelles and many degenerative cells were present. If the estrogenic stimulus was discontinued for 9 months, the pituitary showed evidence of recovery suggesting that these early changes represented hyperplasias rather than true neoplasms. Osamura and Watanabe (1986) localized PRL in well developed RER and Golgi saccules in rats after 4-24 weeks of estrogen treatment. Recent studies by several groups of workers on regression of PRL cell hyperplasia after discontinuation of estrogen treatment have shown decreases in the weight and size of the pituitary gland (Lloyd et al., 1985b; Treip, 1983; Wiklund et al., 1981). However, the gland does not return to the pretreatment weight when compared with the control pituitary glands.

Baskin et al. (1980) examined the ultrastructural features of the MtT/W15 transplantable tumors with immunocytochemical labeling and found that PRL cells had small secretory granules with a mean diameter of $150 \mathrm{~nm}$ while GH was present in larger granules with a mean diameter of $250 \mathrm{~nm}$. The studies of Parsons et al. (1980) with immunocytochemistry revealed that many cells in the MtT/W15 tumors produced either PRL or GH, but that a small percentage of cells produced both PRL and GH. Estrogen treatment in rats with established MtT/W15 tumors has been shown to inhibit tumor growth and to increase GH secretion (Lloyd et al., 1985a). Ultrastructural studies revealed evidence of increased numbers of secretory granules which ranged in size from $100-380 \mathrm{~nm}$ in diameter, prominent RER, and enlarged nuclei and nucleoli. 

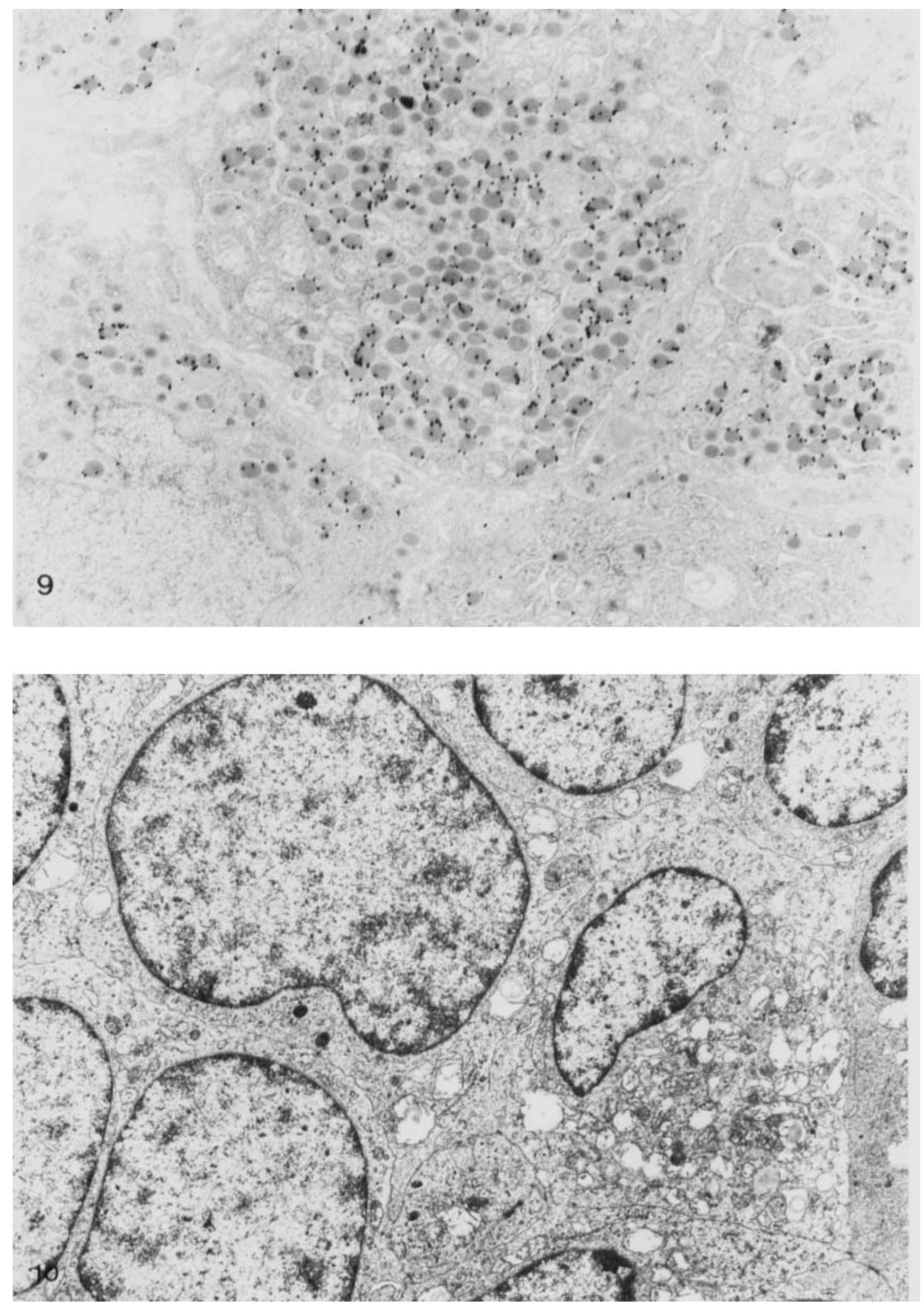

Fig. 9. MtT/W15 tumor from an estrogen treated female rat. Immunolabeling with a rat GH antibody and $40 \mathrm{~nm}$ colloidal gold particles shows that most of the large secretory granules contain immunoreactive GH. $\times 12,200$.
Fig. 10. Transplantable MtT/F4 pituitary tumor. The tumor cells have large nuclei and relatively small amounts of cytoplasm and few secretory granules. $\times 12,000$. 


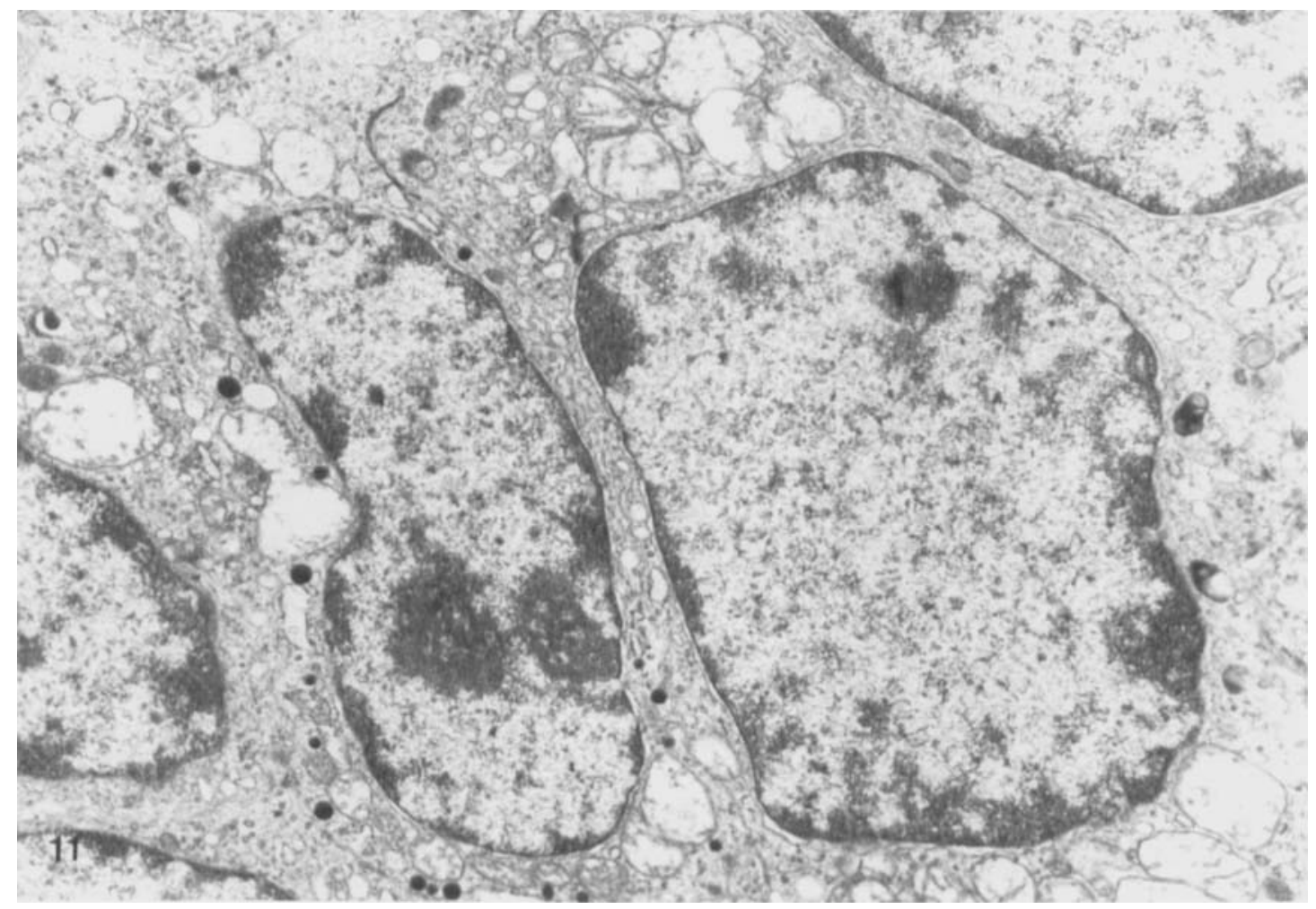

Fig. 11 Transplantable MtT/F4 tumor with a few dense core secretory granules measuring up to 350 $\mathrm{nm}$ in diameter. Some cells have prominent lysosomes. $\times 12,300$.

Estrogen stimulates PRL cell hyperplasia in the rat. Subsequent treatment with ergot alkaloid often leads to an increase in the number of secretory granules in the pituitary cells and decreased PRL secretion (Lloyd et al., 1985a; MacLeod and Lehmeyer, 1973). Estrogens and ergot alkaloids can also modify dopamine receptors as well as inhibit growth of transplantable pituitary tumors (Albaladejo et al., 1984; Ito et al., 1985; Lloyd and Fields, 1986a).

Parsons et al. (1980) observed small virus-like particles in the intercellular space and larger virus-like particles budding into the cisternae of the RER in MtT/ W15 transplantable tumors. The significance of these virus-like particles is not known, and the authors indicated that the tumor secretory function was not altered by the presence of these particles. MtT/W15 tumors also have numerous lysosomes within the tumor cells which may reflect a high degree of intracellular turnover of secretory products.

The ultrastructural studies of McComb et al. (1981) on the MtT/W10 and MtT/W5 tumors showed both PRL and GH immunoreactive granules by ultrastructural studies. The granules varied from $120-280 \mathrm{~nm}$ and frequent exocytosis was noted. Immunolabeled PRL granules ranged from $60-115 \mathrm{~nm}$ while $\mathrm{Gh}$ granules varied from $200-480 \mathrm{~nm}$ in diameter. The MtT/W5 tumors had granules which were $75-190 \mathrm{~nm}$ in diameter, but exocytosis was not seen.

\section{Somatotropic Variants of Transplantable Pituitary Tumors}

Various investigators have described variants of $\mathrm{GH}$ and PRL producing pituitary tumors which produced predominantly $\mathrm{GH}$, including radiation- and chemically-induced transplantable pituitaries (Furth, 1969; Furth et al., 1956; Hollander and Hollander, 1971; MacLeod et al., 1966; Tashjian et al., 1968). Ito et al. $(1972,1985)$ studied the ultrastructural features of these tumors and observed secretory granules ranging in size from 100-300 $\mathrm{nm}$. Similar ultrastructural features were noted by Lloyd et al. in MtT/W15 pituitary tumors after estrogen treatment which resulted in a marked increase in GH production and GH mRNA (Lloyd et al., 1985b, 1988). Hollander and Hollander (1971) noted that this variant was highly malignant with metastatic disease to bone and ovaries.

Makino et al. (1984) established two strains of transplantable rat pituitary tumors in nude mice. They noted that in the MtT/SA5 tumor the concentrations of GH in serum and tumor tissue were exceedingly higher than those of PRL. The cytoplasm of tumor cells had well developed RER, a moderate number of mitochondria, lipid droplets of varying size and numbers, and well developed Golgi regions. Three cell types were observed: 1) cells with many granules of 300-600 nm in diameter and well developed Golgi regions and occa- 
sional exocytosis; 2) cells with moderate numbers of secretory granules of $150-250 \mathrm{~nm}$ in diameter which had frequent exocytosis (RER was in parallel cisternae and well developed); and 3) the third cell type had small granules $100-150 \mathrm{~nm}$ in diameter and in some tumor cells exocytosis was prominent; the cytoplasmic organelles, however, were not well developed. This latter type of cell was few in number.

\section{ACTH Variants of Transplantable Tumors}

Spontaneous tumors secreting ACTH are relatively uncommon in rats. For example, McComb et al. (1984) found less than $4 \%$ of spontaneous adenomas contained ACTH. Ionizing radiation can readily induce transplantable ACTH producing tumors in mice, while in rats various transplantable tumors have been observed to produce ACTH along with PRL and GH. The MtT/F4 transplantable tumors were shown to have ACTH activity after many transplantations (Milkovic et al., 1964). The ACTH levels have been relatively stable over many transplanted generations (Furth et al., 1973, 1976). ACTH production was also observed in the Buffalo rat which was induced with 2,4 6-triethylalamine (Bates et al., 1966). The GH effects of these tumors on various organs can be blocked by ACTH and glucocorticoids which may be the reason animals with GH and ACTH producing tumors do not have marked increases in body and organ weights (Ueda et al., 1968b).

The ultrastructure of the MtT/F4 tumors has been studied by Schelin et al. (1964) (Figs. 9, 10). They reported one type of secretory granule which was round and measured $350 \mathrm{~nm}$ in diameter in some cells, while most cells were devoid of secretory granules. In addition to the usual organelles, lipid droplets, vacuoles, and myelin figures were common in the cytoplasm especially adjacent to necrotic cells. The mitochondria were described as swollen, but this may have been a processing artifact. The ultrastructural immunochemical studies of McComb et al. (1981) on ACTH producing transplantable tumors noted that the MtT/F4 tumors had inconspicuous organelles except for a few cells with many mitochondria. Accumulation of electron dense bodies was also noted and secretory granules were small, measuring $100-190 \mathrm{~nm}$ in diameter and some cells showed exocytosis. Makino et al. (1984) observed that the adrenal glands of nude mice with their MtT/SA5 tumors had adrenocortical hyperplasia which was indirect evidence of ACTH secretion by the tumor. The ultrastructure of the $\mathrm{MtT} / \mathrm{F} 4$ tumors was recently examined by Trouillas et al. (1984). The tumor cells were rich in free ribosomes and small amounts of RER were present while the Golgi region was very limited. Interestingly, after estradiol treatment there was a marked increase in RER which was sometimes vesicular. There was an increase in the numbers of secretory granules after estrogen treatment although most cells remained sparsely granulated. The granule size was $100-150 \mathrm{~nm}$ in diameter. There was an increase in the Golgi region, increase in the euchromatin-rich nuclei, and increased exocytosis after estrogen treatment for 7 days.

\section{ULTRASTRUCTURAL STUDIES OF CULTURED PITUITARY TUMORS}

The establishment of clonal strains of rat pituitary tumor cells has contributed greatly to our knowledge of pituitary neoplasms (Tashjian et al., 1968). The early work of Tashjian et al. (1968) led to the successful cloning of various transplanted cell lines including the MtT/W5 PRL and GH producing tumors. Subsequently other investigators established cell lines from the $\mathrm{MtT} /$ F4 (Richardson, 1976) and the MtT/W15 (McKeel and Hajek, 1981) tumors. PRL secreting cell lines derived from MtT/W15 transplantable pituitary tumors were established as monolayer cultures for up to 18 months. (McKeel and Vaerewyck Hajek, 1981). These cell lines secreted PRL for 18 months, long after GH secretion had ended.

Ultrastructural studies revealed many lipid bodies of complex lysosomes including secondary lysosomes or autophagosomes as prominent cytoplasmic organelles. Typical secretory granules of the type present in solid MtT/W15 tumors were never identified in any subculture of purified cell lines. The cultured cells had less prominent Golgi regions, more disorganized RER, and fewer profiles of fused RER compared with solid tumors growing in vivo. The extended plasma membrane contained delicate microvilli and the mitochondria of the cultured cells were smaller and less numerous than those in the parent tumors. Type $\mathrm{C}$ viral particles were not observed in the purified cell lines. An interesting finding from these studies was that there was a reduced capacity of injected cultured tumor cells to produce tumors in vivo.

The tumor cell lines established by Tashjian et al. (1968) have been designated as GH cells and some of these including the $\mathrm{GH}_{4} \mathrm{C}_{1}$ and $\mathrm{GH}_{3}$ have been studied extensively (Kiino and Dannies, 1981; Scammell et al., 1986). The ultrastructure of the $\mathrm{GH}_{3}$ cells in response to secretagogues has been examined by various groups (Gourdji et al., 1972; Olivier et al., 1975; Tixier-Vidal, 1975; Tougard et al., 1982) (Figs. 12, 13) (Table 3). The control cells had sparse secretory granules which were $50-230 \mathrm{~nm}$ in diameter and close to the cell membrane. The Golgi regions had dilated saccules and several smooth vesicles. Bundles of intermediate filaments were observed in the cytoplasm and tight junctions were present between cells. After thyrotropin releasing hormone (TRH) treatment for a few hours the secretory granules increased in number but remained small; the Golgi regions were hypertrophied and dense bodies were more prominent in the cytoplasm. Using a preembedding saponin permeabilization technique, Tougard et al. (1982) observed that $\mathrm{GH}_{3}$ cells had immunoreactive PRL in the RER and Golgi regions. After 30 minutes-1 hour of TRH treatment the PRL content within the RER and Golgi decreased. This content was restored in some cells above control levels in a few hours. However, treatment with the protein synthesis inhibitor cyclohexamide prevented the restoration of immunoreactive PRL in the Golgi regions and RER.

Recent studies by Scammell et al. (1986) showed that the storage granules of $\mathrm{GH}_{3} \mathrm{C}_{4}$ pituitary cells could also be greatly modified by estrogen treatment. Cells 
R.V. LLOYD
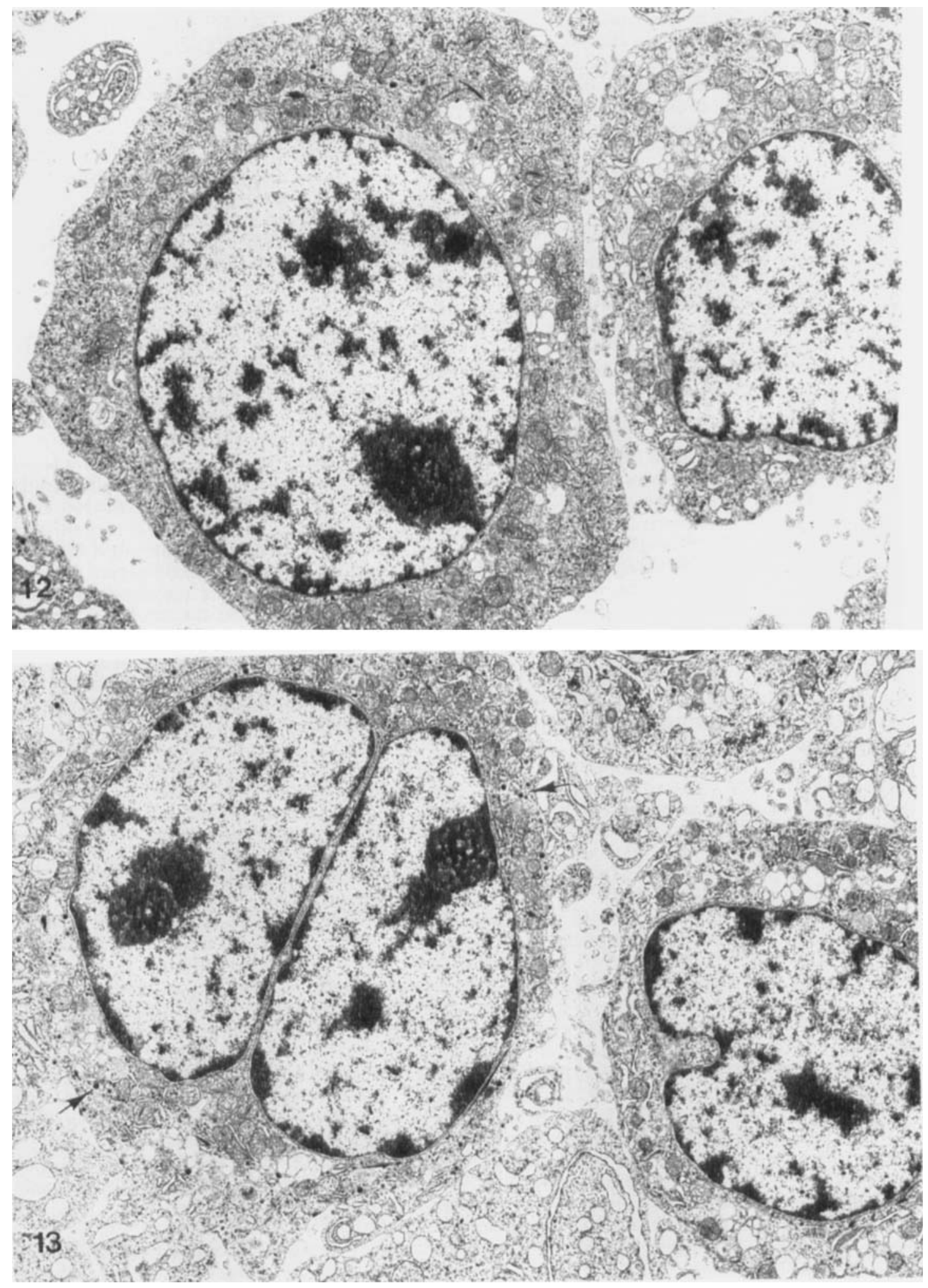

Fig. 12. $\mathrm{GH}_{3}$ tumor cells from cultured medium. The cells have large nuclei and few cytoplasmic organelles or secretory granules. $\times 8,700$.
Fig. 13. $\mathrm{GH}_{3}$ cells cultured in the presence of $10^{-7} \mathrm{M}$ estradiol for 7 days. There is an increase in the number of secretory granules (arrows) which measure up to $200 \mathrm{~nm}$ in diameter. $\times 8,700$. 
TABLE 3. Ultrastructural features of cultured rat pituitary tumor cells ${ }^{1}$

\begin{tabular}{|c|c|c|c|c|c|}
\hline $\begin{array}{l}\text { Tumor } \\
\text { type }\end{array}$ & Treatment & $\begin{array}{l}\text { Hormones } \\
\text { by ICC }\end{array}$ & $\begin{array}{l}\text { Storage } \\
\text { granules }\end{array}$ & RER & $\begin{array}{c}\text { Golgi } \\
\text { region }\end{array}$ \\
\hline $\begin{array}{l}\mathrm{MtT/W15} \\
\mathrm{GH}_{3}\end{array}$ & $\begin{array}{l}\text { None } \\
\text { None }\end{array}$ & $\begin{array}{l}\mathrm{PRL} / \mathrm{GH} \\
\mathrm{PRL} / \mathrm{GH}\end{array}$ & $\begin{array}{l}\text { Very few } \\
\text { Few }\end{array}$ & $\begin{array}{l}\text { Disorganized } \\
\text { Scanty }\end{array}$ & $\begin{array}{l}\text { Sparse } \\
\text { Dilated }\end{array}$ \\
\hline $\begin{array}{l}\mathrm{GH}_{3} \\
\mathrm{GH}_{4} \mathrm{Cl} \\
\mathrm{GH}_{4} \mathrm{Cl} \\
\mathrm{MMQ} \\
\quad(7315 \mathrm{a})\end{array}$ & $\begin{array}{l}\text { TRH } \\
\text { None } \\
\text { Estrogen } \\
\text { None }\end{array}$ & $\begin{array}{l}\text { PRL/GH } \\
\text { PRL/GH } \\
\text { PRL/GH } \\
\text { PRL }\end{array}$ & $\begin{array}{l}\text { Moderate } \\
50-90 \mathrm{~nm} \\
120-160 \mathrm{~nm} \\
\text { Few } \\
\quad 150-300 \mathrm{~nm}\end{array}$ & $\begin{array}{l}\text { Moderate } \\
\text { Moderate } \\
\text { Prominent } \\
\text { Scanty }\end{array}$ & $\begin{array}{l}\text { saccules } \\
\text { Prominent } \\
\text { Sparse } \\
\text { Prominent } \\
\text { Prominent } \\
\text { in some }\end{array}$ \\
\hline
\end{tabular}

Abbreviation: ICC, immunocytochemistry.

${ }^{1}$ Data from Judd et al., 1988; McKeel and Vaerewyck Hajek, 1981; Olivier et al., 1975; Scammell et al., 1986; Tixier-Vidal et al., 1975; Tougard et al,, 1982.

treated with $17 \beta$-estradiol $(1 \mathrm{mM})$, insulin (300 $\mathrm{nM})$, and epidermal growth factor $(10 \mathrm{nM})$ for 5 days had a 30-fold increase in PRL content while GH storage and secretion were decreased. Ultrathin sections of Lowicryl-embedded $\mathrm{GH}_{4} \mathrm{C}_{1}$ cells stained for PRL by the protein-A-gold technique revealed a marked increase in the numbers of secretory granules in these cells which ranged from 120-160 nm in diameter. In contrast control cells had few granules and these measured 50-90 $\mathrm{nm}$ in diameter. Interestingly, by immunolabeling with PRL antibodies, about $25 \%$ of granules had little or no immunoreactive PRL. These granules were also less electron opaque.

Recently, a PRL secreting cell line producing only PRL but not ACTH which was derived from the 7315 a tumor was reported (Judd et al., 1988). Ultrastructural studies revealed that the tumor cells had slender microvilli on their surfaces, large irregular nuclei, and prominent nucleoli. The cytoplasm contained numerous free ribosomes and polysomes. RER was scanty and the Golgi complex was prominent in some cells. Secretory granules were reported as sparse and measured $150-300 \mathrm{~nm}$ in diameter. Variable amounts of lipid droplets and lysosomal bodies were seen. After almost 2 years in culture the biochemical responses and PRL releasing ability of this cell line have been stable. When the tumor cells were injected subcutaneously into rats, tumors developed in vivo after 2 months. This cell line, which as dopamine receptors, should be a good model to examine the regulation of PRL secretion and ultrastructural changes in vitro.

\section{SUMMARY}

Although a great deal of knowledge has accumulated about pituitary cells and tumors in laboratory animals in the last two decades, many problems and questions remain unexplored. The mechanisms governing the development of pituitary tumors in rats during the progression from hyperplasia to neoplasia, the regulation of hormone synthesis and secretion in cells secreting more than one hormone such as PRL-GH secreting cells, and the mechanisms regulating estrogen inhibition of tumor growth in the MtT/W15 and MtT/F4 transplanted tumors are a few of the many questions that should be investigated. Immunocytochemistry at the light and electron microscopic level has contributed to a more precise classification of spontaneous and transplantable pituitary tumors based on specific hor- mone content within secretory granules and other cytoplasmic regions. Further refinements in ultrastructural immunochemical techniques will make this approach more widely applicable for the study of pituitary gland cytology. The use of transgenic animal models such as the GHRH producing transgenic mouse and applications of newer techniques in molecular biology along with ultrastructural and other studies will certainly contribute to our further understanding of the biology and cytology of the pituitary gland.

\section{ACKNOWLEDGMENTS}

This work was supported in part by NIH Grant CA 37238. The author thanks Ms. Kristina Fields, Ms. Maria Cano, Dr. L. Jin, and Dr. J Song for technical assistance.

\section{REFERENCES}

Albaladejo, V., Collu, R., and Andre, J. (1984) Down-regulation by 17 beta-estradiol of $\mathrm{D} 2$ dopamine receptors in the $\mathrm{MtT} / 4$ pituitary tumor. Endocrinology, 144:2344-2348.

Barsoum, N.J., Moore, J.D., Gough, A.W., Sturgess, J.M., and De La Iglesia, A. (1985) Morphofunctional investigations on spontaneous pituitary tumors in Wistar rats. Toxicol. Pathol., 13:200-208.

Baskin, D.G., Erlandsen, S.L., and Parsons, J.A. (1980) Functional classification of cell types in the growth hormone-and prolactinsecreting rat MtT/W15 mammosomatotropic tumor with ultrastructural immunocytochemistry. Am. J. Anat., 158:455-461.

Bates, R.W., Scow, R.O., and Lacy, P.E. (1966) Induction of permanent diabetes in rats by pituitary hormones from a transplantable mammotropic tumor. Concomitant changes in organ weights and the effect of adrenalectomy. Endocrinology, 78:826-836.

Beech, J. (1981) Pituitary tumors in the horse. In: Current Veterinary Therapy. N.E. Robinson, ed. W.B. Saunders Co., Philadelphia, pp. 164-169.

Bendayan, M., Nanci, A., Herbener, G.H., Gregoire, S., and Duhr, M.A. (1986) A review of the study of protein secretion applying the protein A-gold immunocytochemical approach. Am. J. Anat., 175: $379-400$

Boorman, G.A., and Hollander, C. (1973) Spontaneous lesions in the female WAG/Rij (Wistar) rat. J. Gerontol., 28:152-159.

Carlton, W.W., and Gries, C.L. (1983) Adenoma and carcinoma, pars distalis, rat. In: Endocrine System. T.C. Jones, U. Mohr, and R.D. Hunt, eds. Springer-Verlag, New York, pp. 134-145.

Clayton, C.J., Schechter, J., and Finch, C.E. (1984) The development of mammotroph adenomas in pituitaries of aging female $\mathrm{C} 57 \mathrm{BL} / 6 \mathrm{~J}$ mice. Exp. Gerontol., 19:313-320.

Cliffon, K.H., and Meyer, R.K. (1956) Mechanisms of anterior pituitary tumor induction by estrogen. Anat. Rec., 125:65-81.

Coffin, D.L., and Munson, T.O. (1953). Endocrine diseases of the dog associated with hair loss: sertoli cell tumor of testis, hypothyroids in canine Cushing's syndrome. J. Am. Vet. Med. Assoc., 123:402-408.

Costoff, A. (1973) Ultrastructure of Rat Adenohypophysis. Correlation With Function. Academic Press, New York, pp. 1-207.

El Eltreby, M., Schilk, B., Soulioti, G., Tushaus, U., Wiemann, H., and 
Gunzel, P. (1977) Effect of 17b-estradiol on cells of the pars distalis of the adenohypophysis in the beagle bitch: an immunocytochemical and morphometric study. Endocrinologie, 69:202-216.

Elias, K.A., and Weiner, R.I. (1984) Direct arterial vascularization of estrogen-induced prolactin-secreting anterior pituitary tumors. Proc. Natl. Acad. Sci., U.S.A., 81:4549-4553.

Frawley, L.S., Boockfor, R., and Hoeffler, J.P. (1985a) Identification by plaque assays of a pituitary cell type that secretes both growth hormone and prolactin. Endocrinology, 116:734-737.

Frawley, L.S., Hoeffler, J.P., and Boockfor, R. (1985b) Functional maturation of somatotropes in fetal rat pituitaries: analysis by reverse hemolytic plaque assays. Endocrinology, 116:2355-2360.

Furth, J. (1955) Experimental pituitary tumors. Recent Prog. Horm. Res., 11:221-255.

Furth, J. (1969) Pituitary Cybernetics and Neoplasia. Academic Press, New York, Harvey Lecture Series, No. 63. pp. 47-71.

Furth, J., and Clifton, K.H. (1966) Experimental pituitary tumors. In: The Pituitary Gland. Vol. 2. G. Harris and B. Donovan, eds. London, Butterworths, pp. 460-497.

Furth, J., Clifton, K.M., Gadner, E.L., and Buffet, R. (1956) Dependent and autonomous mammotropic pituitary tumors in rats: their somatotropic features. Cancer Res., 16:608-616.

Furth, J., Nakane, P., and Pasteels, J.L. (1976) Tumours of the pituitary gland. In: Pathology of Tumours in Laboratory Animals. V.S. Turusov, ed. International Agency for Research on Cancer. Scientific Publication. Vol. 1, Part 2. Lyon, pp. 201-237.

Furth, J., Ueda, G., and Clifton, K.H. (1973) The pathophysiology of pituitaries and their tumors: methodological advances. In: Methods in Cancer Research. Vol. X. Academic Press, New York, pp. 201277.

Gardner, W.U., Pfeiffer, C.A., Trentin, J.J., and Wolstenholme, J.T. (1953) Hormonal factors in experimental carcinogenesis. In: The Pathophysiology of Cancer. 2nd Ed. F. Homberger and W.H. Fishman, eds. Harper (Hoeber), New York, pp. 225-297.

Gee, C.E., and Roberts, J.L. (1983) In situ hybridization histochemistry: a technique for the study of gene expression in single cells. DNA, 2:157-163.

Gorbman, A. (1956) Pituitary tumors in rodents following changes in thyroid function: a review. Cancer Res., 16:99-105.

Gordon, M.N., Schechter, J.E., Felicio, L.S., and Finch, C.E. (1987) Spontaneous tumors in aging female mice are more prevalent in the lateral pituitary zones. Neurobiol. Aging, 8:67-70.

Gourdji, D., Kerdelhue, B., and Tixier-Vidal, A. (1972) Ultrastructure d'un clone de cellules hypophysaires secretant de la prolactine (clone $\mathrm{GH}_{3}$ ). Modifications induites par l'hormone hypothalamique de libéeration de l'hormone thyréotrope (TRF). C.R. Acad. Sci., Ser. D 274:437-440.

Hammer, R.E., Brinster, R.L., Rosenfeld, M.G., Evans, R.M., and Mayo, K.E. (1985) Expression of human growth hormone-releasing factor in transgenic mice results in increased somatic growth. Nature, 315:413-416.

Hollander, N., and Hollander, V.P. (1971) Development of a somatotropic variant of the mammosomatotropic tumor MtT/W5. Proc. Soc. Exp. Biol. Med., 137:1157-1162.

Horvath, E., and Kovacs, K. (1988) Fine structural cytology of the adenohypophysis in rat and man. J. Electron Microsc. Tech. 8:401432.

Ito, A., Furth, J., and Moy, P. (1972) Growth hormone secreting variants of a mammotropic tumor. Cancer Res., 32:48-56.

Ito, A., Kawashima, K., Fujimoto, N., Watanabe, H., and Naito, M. (1985) Inhibition by 2-bromo-a-ergocriptine and tamoxifen of the growth of an estrogen-dependent transplantable pituitary tumor (MtT/84) in 344 rats. Cancer Res., 45:6436-6441.

Judd, A.M., Login, I.S., Kovacs, K., Ross, P.C., Spangelo, B.L., Jarvis, W.D. and MacLeod, R.M. (1988) Characterization of the MMQ cell a prolactin-secreting clonal cell line that is responsive to dopamine. Endocrinology, 123:2341-2350.

Kao, K.J., and Ramirez, V.D. (1979) Induction of pituitary and mammary tumors in male, "fale" and female rats by either DMBA, estradiol implant or combined treatment. Proc. Soc. Exp. Biol. Med., 160:296-301.

Khachaturian, H., Sherman, T.G., Lloyd, R.V., Civelli, O., Douglas, J., Herbert, E.D., Akil, H., and Watson, S.J. (1986) Pro-dynorphin is endogenous to the anterior pituiary and is co-localized with $\mathrm{LH}$ and FSH in the gonadotroph. Endocrinology, 119:1409-1411.

Kiino, D.R., and Dannies, P.S. (1981) Insulin and 17ß-estradiol increases the intracellular prolactin content of $\mathrm{GH}_{4} \mathrm{C}_{1}$ cells. Endocrinology, 109:1264-1269.
Kovacs, K., and Horvath, E. (1986) Tumors of the Pituitary Gland Atlas of Tumor Pathology. Second Series, article 21. Armed Forces Institute of Pathology, Washington, D.C., pp. 1-264.

Kwa, H.G. (1961) An Experimental Study of Pituitary Tumors: Genesis, Cytology and Hormone Content. Springer Verlag, Berlin.

Liebelt, A.G. (1979) Tumours of the pituitary gland. In: Pathology of Tumours in Laboratory Animals. V.S. Turusov, ed. International Agency for Research on Cancer. Scientific Publications. Vol, 1. Lyon, pp. 411-440.

Liehr, J.G., Avitts, T.A., Randerath, E., and Randerath, K. (1986) Estrogen induced endogenous DNA adduction: possible mechanisms of hormonal cancer. Proc. Natl. Acad. Sci. U.S.A., 83:53015305.

Lloyd, H.M., Meares, J.D., Jacobi, J. (1973) Early effects of stilboestrol on growth hormone and prolactin secretion and on pituitary mitotic activity in the male rat. J. Endocrinol., 58:227-231.

Lloyd, R.V. (1983) Estrogen induced hyperplasia and neoplasia in the rat anterior pituitary gland. An immunohistochemical study. Am. J. Pathol., 113:198-206.

Lloyd, R.V. (1987) Analysis of prolactin and growth hormone production in the MtT/F4 transplantable pituitary tumor by the reverse hemolytic plaque assay. Am. J. Pathol., 129:441-447.

Lloyd, R.V., Cano, M., and Landefeld, T.D. (1988) The effects of estrogens on tumor growth and on prolactin and growth hormone mRNA expression in rat pituitary tissues. Am. J. Pathol., 133:397-406.

Lloyd, R.V., Coleman, K., Fields, K., and Nath, V. (1987b) Analysis of prolactin and growth hormone production in hyperplastic and neoplastic rat pituitary tissues by the hemolytic plaque assay. Cancer Res., 47:1087-1092.

Lloyd, R.V., and Fields, K.L. (1986a) Regulation of dopamine receptors in MtT/W15 transplantable pituitary tumor by estrogen. Mol. Cell. Endocrinol., 44:133-139.

Lloyd, R.V., Hawkins, K.L., and Jin, L. (1989) Analysis of spontaneous pituitary tumors in aged female rats by in situ hybridization and immunohistochemistry. Lab. Invest., 60:54A (abstract 322).

Lloyd, R.V., and Landefeld, T.D. (1986b) Detection of prolactin messenger RNA in rat anterior pituitary by in situ hybridization. Am. J. Pathol., 125:35-44.

Lloyd, R.V., Landefeld, T.D., Maslar, I., and Frohman, L.A. (1985a) Diethylstilbestrol inhibits tumor growth and prolactin production in rat pituitary tumours. Am. J. Pathol., 118:379-386.

Lloyd, R.V., Schmidt, K., and Nath, V. (1985b) Effects of pergolide on diethylstilbestrol-induced rat pituitary hyperplasia. Am. J. Pathol. 121:486-495.

MacLeod, R.M., and Lehmeyer, J.E. (1973) Suppression of pituitary tumor growth and function by ergot alkaloids. Cancer Res., 33: $849-855$.

MacLeod, R.M., Smith, M.C., and DeWitt, G.W. (1966) Hormonal properties of transplanted pituitary tumors and their relation to the pituitary gland. Endocrinology, 79:1149-1156.

Majeed, S.K., Gopinath, C., and Magnusson, G. (1980) Ultrastructure of spontaneous pituitary neoplasms in the rat. J. Comp. Pathol., 90:239-246

Makino, S., Mori, H., Koizumi, K., Yamashita, H., Hayashi, Y., Aono, T., and Matsumoto, K. (1984) Functional and morphological characteristics of transplantable rat pituitary tumors established in nude mice. Cancer Res., 44:4487-4495.

Mayo, K.E., Hammer, R.E., Swanson, L.W., Brinster, R.L., Rosenfeld, M.G., and Evans, R.M. (1988) Dramatic pituitary hyperplasia in transgenic mice expressing a human growth hormone-releasing factor gene. Mol. Endocrinol., 2:606-612.

McComb, D.J., Kovacs, K., Beri, J., and Zak, F. (1984) Pituitary adenomas in old Spague-Dawley rats: a histologic, ultrastructural and immunocytochemical study. J. Natl. Cancer Inst., 73:11431166 .

McComb, D.J., Ryan, N., Horvath, E., Kovacs, K., Nagy, E., Berczl, I., Domokos, I., and Laszlo, F.A. (1981) Five different adenomas derived from the rat adenohypophysis: immunocytochemical and ultrastructural study. J. Natl. Cancer Inst., 66:1103-1111.

McComb, D.J., Ryan, I.N., Horvath, E., Kovacs, K., Nagy, E., and Berczi, I. (1980) Histologic, immunocytologic and subcellular changes in the rat adenohypophysis caused by prolactin, growth hormone and ACTH-producing transplanted pituitary tumors: a comparison with spontaneous prolactin-producing adenomas. Exp. Pathol., 18:213-222.

McComb, D.J., Ryan, N., Horvath, E., Kovacs, K., Beri, J., Zak, F., Milligan, J.V., and Shin, S.H. (1985) Pituitary gonadotroph ade- 
noma in old Sprague-Dawley rats. J. Submicrosc. Cytol., 17:517530.

McEuen, C.S., Selye, H., and Collip, J.B. (1936) Some effects of prolonged administration of oestrin in rats. Lancet, 1:775-776.

McKeel, D.W., Vaerewyck Hajek, S.A. (1981) Characterization of long term hormonal cell culture from the MtT/W15 prolactin and growth hormone secreting rat pituitary tumor. Endocrinology, 108:15711586 .

Milkovic, S., Garrison, M., and Bates, R. (1964) Study of the hormonal control of body and organ size in rats with mammosomatotropic tumors. Endocrinology, 75:670-691.

Morel, Y., Albaladejo, V., Bouvier, J., and Andre, J. (1982) Inhibition by 17 beta-estradiol of the growth of the rat pituitary transplantable tumor MtT/F4. Cancer Res., 42:1492-1497.

Olıvier, L., Vila-Porcile, E., Racadot, O., Peillon, and Racadot, J. (1975) Ultrastructure of pituitary tumor cells: a critical study. In The Anterior Pituitary. A. Tixier-Vidal and M.G. Farquhar, eds. Academic Press, New York, pp. 231-276.

Osamura, R.Y., and Watanabe, K. (1986) Ultrastructural localization of prolactin in estrogen-induced prolactinoma of the rat pituitary. Experimental models for the human prolactinomas and the effects of bromocriptine. Acta Pathol. Jpn., 36:1131-1137.

Palmiter, R.D., Brinster, R.L., Hammer, R.E., Trumbauer, M.E., Rosenfeld, M.G., Birnbey, N.C., and Evans, R.M. (1982) Dramatic growth of mice that develop from eggs microinjected with metallothionein-growth hormone fusion genes. Nature, 300:611-615.

Parsons, J.A., Baskin, D.G., and Erlandsen, S.I. (1980) Heterogeneity of the $\mathrm{M}+\mathrm{T} / \mathrm{W} 15$ mammosomatotropic tumor II. Characterization of parenchymal cells by superimposition immunocytochemistry and electron microscopy. Anat. Rec., 196:301-311.

Pasteels, J.L., Gausset, P., Danguy, A., Ectors, P., Nicoll, C.S., and Varavudhi, P. (1972) Morphology of the lactotropes and somatotropes of man and Rhesus monkey. J. Clin. Endocrinol. 34:959-967.

Pharaboz, M.O., Morel, Y., and Andre, J. (1984) Dual effects of estradiol on normal and tumour pituitary cell multiplication. J. Steroid Biochem., 20:421-424.

Richardson, U.I. (1976) Establishment in culture of a multihormonesecreting cell strain derived from the MtT/F4 rat pituitary tumor. J. Cell Physiol., 88:287-296.

Ross, M., Bras, G., and Ragbeer, M. (1970) Influence of protein and caloric intake upon spontaneous tumour incidence of the anterior pituitary gland of the rat. J. Nutr., 100:177-189.

Russfield, A. (1975) Experimental endocrinopathies. Methods Achiev. Exp. Pathol., 7:132-148.

Russfield, A.B. (1963) Biological characteristics of two transplantable pituitary tumors of syrian hamsters. Cancer Res., 23:720-725.

Russfield, A.B. (1966) Pituitary anterior lobe. In: US Department of Health, Education and Welfare, Tumors of Endocrine Glands and Secondary Organs. U.S. Government Printing Office, Washington, D.C. (Public Health Service Publication no. 1332), pp. 3-22.

Sandusky, G.E., Van Pelt, C.S., Todd, G.C., and Wrightman, K. (1988) An immunocytochemical study of pituitary adenomas and focal hyperplasia in old Sprague-Dawley and Fischer 344 rats. Toxicol. Pathol., 16:376-380.

Sano, T., Kovacs, K., Stefaneanu, L., Asa, S.L., and Snyder, D.L. (1989) Spontaneous pituitary gonadotroph nodules in aging male Lobund-Wistar rats. Lab. Invest., 61:343-349.

Sarkar, D.K., Gottschall, P.E., and Meites, J. (1982) Damage to hypothalamic dopaminergic neurons is associated with development of prolactin-secreting pituitary tumors. Science, 218:684-686.
Scammell, J.G., Burrage, T.G., and Dannies, P.S. (1986) Hormonal induction of secretory granules in a pituitary tumor cell line. Endocrinology, 119:1543-1548.

Schelin, U., Lundin, P.M., and Bartholdson, L. (1964) Light and electron microscopic studies on an autonomous stilbestrol-induced pituitary tumor in rats. Endocrinology, 75:893-900.

Schlumberger, H.G. (1956) Neoplasia in the parakeet. II. Transplantation of the pituitary tumor. Cancer Res., 16:149-153.

Schlumberger, H.G., and Rudolph, H.J. (1959) Growth-promoting effect of a transplantable pituitary tumor in parakeets. Endocrinology, 65:902-908.

Song, J., Jin, L., and Lloyd, R.V. (1989) Effects of estradiol on prolactin and growth hormone messenger RNAs in cultured normal and neoplastic (MtT/W15 and $\mathrm{GH}_{3}$ ) rat pituitary cells. Cancer Res., 49: $1247-1253$

Stefaneaunu, L., Kovacs, K., Horvath, E., Asa, S.L., Losinski, N.E., Billestrup, N., Price, J. and Vale, W. (1989) Adenohypophysial changes in mice transgenic for human growth hormone-releasing factor (hGRF): a histologic immunocytochemical and electron microscopic investigation. Endocrinology, 125:2710-2718.

Stoica, G., and Koestner, L.A. (1984) Diverse spectrum of tumors in male Sprague-Dawley rats following single high doses of N-ethylN-nitrosourea (ENU). Am. J. Pathol., 116:319-326.

Tashjian, A.H. Jr., Yasumura, Y., Levine, L., Sato, G.H., and Parker, M.L. (1968) Establishment of clonal strains of rat pituitary tumor cells that secrete growth hormone. Endocrinology, 82:342-352.

Tixier-Vidal, A. (1975) Ultrastructure of anterior pituitary cells in culture. In: The Anterior Pituitary. A. Tixier-Vidal and M.G. Farquher, eds. Academic Press, New York, pp. 181-229.

Tougard, C., Picart, R., and Tixier-Vidal, A. (1982) Immunocytochemical localization of prolactin in the endoplasmic reticulum of $\mathrm{GH}_{3}$ cells. Variation in response to thyroliberin. Biol. Cell 43:89-101.

Treip, C.S. (1983) The regression of oestradiol-induced pituitary tumours in the rat. J. Pathol., 141:29-40.

Trouillas, J., and Girod, C. (1988) Animal models of human pituitary tumors. Path. Res. Pract., 183:638-641.

Trouillas, J., Morel, Y., Pharaboz, M.O., Cordier, G., Girod, C., and Andre, J. (1984) Morphofunctional modifications associated with the inhibition by estradiol of MtT/F4 rat pituitary tumor growth. Cancer Res., 44:4046-4052.

Ueberberg, H., and Lutzen, L. (1979) The spontaneous rate of tumours in the laboratory rat: strain Chbb Thom (SP). Drug Res., 29:18761879.

Ueda, G., Otsuka, J., Mori, T., and Nagai, K. (1968a) An immunohistochemical study of estrogen-induced pituitary adenoma in rat. Wakayama Med. Rep., 13:49-58.

Ueda, G., Takizawa, S., Moy, P., Marolla, J., and Furth, J. (1968b) Characterization of four transplantable mammotropic pituitary tumor variants in the rat. Cancer Res., 28:1963-1975.

Ueda, G., Tanizawa, O., Hamanaka, N., and Nishiura, H. (1970) Changes of growth hormone-containing cells during tumorigenesis and subpassages of estrogen-induced pituitary tumors in rats. Endocrinol. Jpn., 17:447-452.

Watari, N., and Tsukagoshi, N. (1968) Electron microscopic observations on the estrogen-induced pituitary tumours. Proc. Gunma Symp. Endocrinol., 6:297-313.

Wiklund, J., Wertz, N., and Gorski, J. (1981) A comparison of estrogen effects on uterine and pituitary growth and prolactin synthesis in 344 and Holtzman rats. Endocrinology, 109:1700-1707.

Zondek, B. (1936) Tumour of the pituitary induced with follicular hormone. Lancet, 1:776-778. 